\title{
Does Hypertension Alone Increase Mortality in Young Hypertensive Patients Having COVID-19? Single Center Retrospective Study of 100 Patients
}

\author{
COVID-19 lu Genç Hipertansif Hastalarda, Hipertansiyon Tek Başına Mortaliteyi Artırır \\ Mı? 100 Hasta ile Tek Merkez Retrospektif Çalış̧a
}

\author{
Mustafa KUZEYTEMIZI
}

$\underline{\underline{O} Z}$

Amaç: Hipertansiyonun, tek başına COVID-19 bulgularının şiddeti ve COVID-19 kaynaklı mortalite için bağımsız bir risk faktörü olup olmadığı hala açık değildir. Bu çalışmada, önceden hipertansiyonu olan ve olmayan COVID-19 hastalarını klinik özellikler ve laboratuvar ölçümleri açısından karşılaştırarak hipertansiyonun tek başına COVID-19 seyrine etkisini araştırmak amaçlandı.

Araçlar ve Yöntem: Önceden hipertansiyonu olan ancak başka hiçbir kronik hastalığı olmayan 45 yaşından küçük 50 COVID-19 hastası, 50 normotansif COVID-19 hastasıyla karşılaştıııldı. Tüm hastalar aynı tedavi protokolünü aldı. Gruplar arasında semptomların sıklığı, inflamatuvar belirteçlerin kan düzeyleri, hastanede kalış süresi, yoğun bakım ünitesi(YBÜ) gereksinimi ve ölüm oranları karşılaştırıldı. Bulgular: Hipertansif grupta normotansif grupla karşılaştırıldığında tepe lökosit sayısı $\left(8,1 \pm 2,7 \times 10^{3} / \mathrm{mm}^{3} \mathrm{vs} .6,9 \pm 1,9 \times 10^{3} / \mathrm{mm}^{3}, \mathrm{p}=0.012\right)$, tepe C-reaktif protein $(52.7 \pm 9.7 \mathrm{mg} / \mathrm{L}$ vs. $18.9 \pm 3.7 \mathrm{mg} / \mathrm{L}, \mathrm{p}=0.024)$, ve tepe eritrosit sedimentasyon hizı $(55.5 \pm 5.7 \mathrm{~mm} / \mathrm{h}$, vs. $33.4 \pm 5.1$ $\mathrm{mm} / \mathrm{h}, \mathrm{p}<0.01$ ) anlamlı derecede yüksekti ( tüm değerler sırasıyla). Hastanede yatiş süresi hipertansif grupta normotansif gruba göre önemli oranda uzundu (hipertansif grupta11 \pm 2.4 gün; normotansif grupta $9.1 \pm 2.2$ gün, $\mathrm{p}=0.001$ ).

Sonuç: Hipertansiyonu olan COVID-19 hastaları, hipertansiyonu olmayan COVID-19 hastalarına kıyasla daha yüksek seviyelerde inflamatuar belirteçlere, daha yüksek troponin seviyelerine ve daha uzun hastanede kalış sürelerine sahiptir. Görüldüğüne göre hipertansif hastalar normotansif olanlara göre COVID-19 enfeksiyonunu daha şiddetli geçirme eğilimindedir.

Anahtar Kelimeler: COVID-19; hipertansiyon; mortalite; SARS-CoV-2

\section{ABSTRACT}

Purpose: Whether hypertension is an independent risk factor for the severity of COVID-19 symptoms and COVID-19 mortality is still unclear. In this study, it was aimed to investigate the effect of hypertension independently in the course of COVID-19 by comparing clinical characteristics and laboratory measurements in COVID-19 patients with and without preexisting hypertension.

Materials and Methods: Fifty COVID-19 patients under the age of 45 with preexisting hypertension without accompanying chronic diseases were compared with 50 normotensive COVID-19 patients. All patients received the same treatment protocol. The frequency of symptoms, blood levels of inflammatory markers, length of hospital stay, intensive care unit (ICU) requirement, and mortality rates were compared between the groups.

Results: Peak leukocyte count $\left(8.1 \pm 2.7 \times 10^{3} / \mathrm{mm}^{3}\right.$ vs. $\left.6.9 \pm 1.9 \times 10^{3} / \mathrm{mm}^{3}, \mathrm{p}=0.012\right)$, peak C-reactive protein $(52.7 \pm 9.7 \mathrm{mg} / \mathrm{L}$ vs. $18.9 \pm 3.7$ $\mathrm{mg} / \mathrm{L}, \mathrm{p}=0.024)$, and peak erythrocyte sedimentation rate (ESR) $(55.5 \pm 5.7 \mathrm{~mm} / \mathrm{h}$, vs. $33.4 \pm 5.1 \mathrm{~mm} / \mathrm{h}, \mathrm{p}<0.01)$ were significantly higher in hypertensive patients compared to normotensive ones (all values respectively). Hospital stay duration was significantly longer in hypertensive patients than the normortensive ones. (hypertensive group $11 \pm 2.4$ days; normotensive group $9.1 \pm 2.2$ days, $\mathrm{p}=0.001$ ).

Conclusions: COVID-19 patients having hypertension have higher levels of inflammatory markers, higher levels of troponin, and longer hospital stay compared to COVID-19 subjects without hypertension. It appears that hypertensive patients tend to have a more severe COVID-19 infection than normotensive patients.

Key Words: COVID-19; hypertension; mortality; SARS-CoV-2

Received: 23.12.2020; Accepted: 05.07.2021

${ }^{1}$ Department of Cardiology, SBU Bursa High Specialty Training and Research Hospital, Bursa, Turkey.

Corresponding Author: Dr. Mustafa Kuzeytemiz. Department of Cardiology, SBU Bursa High Specialty Training and Research Hospital, Bursa, Turkey. e-mail: mustafakuzeytemiz@gmail.com

How to cite: Kuzeytemiz M. Does hypertension alone increase mortality in young hypertensive patients having covid-19? single center retrospective study of 100 patients. Ahi Evran Med J. 2021;5(3):223-228. DOI: 10.46332/aemj.845972 


\section{INTRODUCTION}

COVID-19 was first reported in Wuhan, Hubei Province, China on 31 December 2019. ${ }^{1,2}$ As of 10 November 2020, there have been 51 million confirmed cases of COVID-19 reported worldwide, with 1.2 million deaths. Lack of a specific antiviral treatment is considered to be the main cause of increased mortality. ${ }^{1}$

According to the evidence, older people with comorbid cardiovascular diseases, hypertension, and diabetes are at risk of developing severe COVID-19 requiring intensive care. $^{3-9}$ Hypertension was found to be the most common comorbid disease in initial reports from Wuhan, China. ${ }^{4}$ However, COVID-19 patients with hypertension commonly have older age or additional comorbidities which can, in turn, lead to poor prognosis. ${ }^{10-12}$ Therefore, whether hypertension itself contributes to severe COVID-19 and its impact on mortality from COVID-19 is still a matter of clarification.

This retrospective study aimed to compare COVID-19 patients with and without preexisting hypertension in terms of clinical findings and laboratory measurements.

\section{MATERIAL and METHODS}

This retrospective study was performed using the data of COVID-19 patients with hypertension who admitted to our institute from April 1 to May 30, 2020. The local ethics committee approved this study (Approval no: 2020/45-33 date: 07.05.2020) that was conducted in accordance with the Helsinki declaration. Written informed consent was obtained from all patients. COVID-19 diagnosis was confirmed by both Polymerase chain reaction (PCR) and chest computed tomography (CT).

Fifty subjects aged <45 years, who had preexisting hypertension without other chronic medical disorders, were compared with 50 age- and gender-matched normotensive COVID-19 patients who had no chronic medical diseases. All patients had hypertension diagnosis previously and were under anti-hypertensive treatment with various types of antihypertensive agents being followed by cardiology and internal medicine outpatient clinics. In their medical history, all these hypertensive subjects had the diagnosis of primary hypertension after undergoing several laboratory, imaging and other investigations to exclude secondary hypertension.

All patients received the same treatment protocol according to the interim guidelines established by the Turkish Ministry of Health. During the treatment, clinical and laboratory findings were followed.

Clinical features and laboratory test results monitored during hospitalization were taken from the institutional digital database. The difference between hypertensive and normotensive COVID-19 patients in terms of the frequency of symptoms, blood levels of inflammatory markers, duration of hospital stay, and the rate of ICU requirement was accepted as the primary outcome.

\section{Statistical Analysis}

All statistical analyses were performed by using SPSS 24.0 (IBM Corp. Released 2011. IBM SPSS Statistics for Windows, Version 20.0 Armonk, NY: IBM Corp.).

Continuous variables with normal distribution were expressed as mean \pm standard deviation (SD), and continuous variables without normal distribution were expressed as median and interquartile range (IQR). Categorical data were expressed as absolute values and percentages. Shapiro-Wilk test was used to test the normal distribution. Differences in continuous variables between groups were determined by students' $t$-test or Mann-Whitney U-test for variables with or without normal distribution, respectively. Categorical variables and proportions were analyzed by the chi-square test. Statistical significance level was accepted as $\mathrm{p}<0.05$.

\section{RESULTS}

Fifty patients with COVID-19 and hypertension (mean age $37.4 \pm 5.5$ years, $56 \%$ male) and 50 age-matched COVID-19 patients without hypertension (mean age $37.3 \pm 5.5$ years, $54 \%$ male) were included in this study. Body mass indices were comparable in both patient groups $\left(21.0 \pm 1.1 \mathrm{~kg} / \mathrm{m}^{2}\right.$ for 
hypertensive group, $20.6 \pm 0.9 \mathrm{~kg} / \mathrm{m}^{2}$ for normotensive group, $\mathrm{p}=0.34)$.

In the hypertensive group, the patients used ACE inh/ARB in 14 cases (28\%), calcium channel blocker in 26 cases (52\%), beta-blocker and a diuretic in 10 subjects (20\%). All patients' blood pressures were under control of $110 \pm 4$ $\mathrm{mmHg}$. During the in-hospital treatment phase, all subjects continued having their anti-hypertensive treatment as previously.

Age, gender, and body weight were statistically similar in both groups. The groups were also similar concerning the agents used for the treatment of COVID-19 (Table 1).

Table 1. Clinical characteristics of study subjects

\begin{tabular}{|c|c|c|c|}
\hline Variables & $\begin{array}{l}\text { Hypertensive } \\
(\mathbf{n}=50)\end{array}$ & $\begin{array}{l}\text { Normotensive } \\
(\mathbf{n}=\mathbf{5 0})\end{array}$ & $\mathbf{p}$ \\
\hline Age(year) & $37.4 \pm 5.5$ & $35.9 \pm 6.1$ & 0.872 \\
\hline Gender (male) & $28(56 \%)$ & $27(54 \%)$ & 0.841 \\
\hline \multicolumn{4}{|c|}{ Agents used for COVID-19 } \\
\hline $\begin{array}{l}\text { Hydroxychloroquine, } \\
\mathrm{n}\end{array}$ & $50(100 \%)$ & $50(100 \%)$ & 0.999 \\
\hline Favipiravir, $\mathrm{n}$ & $48(96 \%)$ & $48(96 \%)$ & 0.999 \\
\hline LMWH, n & $50(100 \%)$ & $48(96 \%)$ & 0.495 \\
\hline Azithromycin, $\mathrm{n}$ & $50(100 \%)$ & $50(100 \%)$ & 0.999 \\
\hline Antibiotics, $\mathrm{n}$ & $30(60 \%)$ & $20(40 \%)$ & 0.161 \\
\hline \multicolumn{4}{|l|}{ Symptoms } \\
\hline Fever, $\mathrm{n}$ & $50(100 \%)$ & $50(100 \%)$ & 0.999 \\
\hline Cough, $\mathrm{n}$ & $44(88 \%)$ & $45(90 \%)$ & 0.269 \\
\hline Dyspne, $\mathrm{n}$ & $40(80 \%)$ & $38(76 \%)$ & 0.810 \\
\hline Sore throat, $\mathrm{n}$ & $16(32 \%)$ & $20(40 \%)$ & 0.532 \\
\hline Hedache, $\mathrm{n}$ & $22(44 \%)$ & $20(40 \%)$ & 0.840 \\
\hline
\end{tabular}

Additional to the drugs for COVID-19, some patients (30 cases in hypertensive arm, 20 in normotensive arm) in both groups received second antibiotics, such as amoklavin and ciprofloxacin for pharyngitis, tonsillitis, and cystitis.

Table 2 shows laboratory measurements throughout the hospital stay. Peak leukocyte count $\left(8.1 \pm 2.7 \times 10^{3} / \mathrm{mm}^{3}\right.$ vs. $6.9 \pm 1.9 \times 10^{3} / \mathrm{mm}^{3}, \mathrm{p}=0.012$ ), peak C-reactive protein $(52.7 \pm 9.7 \mathrm{mg} / \mathrm{L}$ vs. $18.9 \pm 3.7 \mathrm{mg} / \mathrm{L}, \mathrm{p}=0.024)$, and peak erythrocyte sedimentation rate $(\mathrm{ESR})(55.5 \pm 5.7 \mathrm{~mm} / \mathrm{h}$, vs. $33.4 \pm 5.1 \mathrm{~mm} / \mathrm{h}, \mathrm{p}<0.01)$ were significantly higher in hypertensive patients compared to normotensive ones. Moreover, peak D-dimer $(1490 \pm 260 \mathrm{ng} / \mathrm{mL}$ vs. $610 \pm 63$ $\mathrm{ng} / \mathrm{mL}, \mathrm{p}=0.025)$, and peak troponin I $(18.6 \pm 4.9 \mathrm{ng} / \mathrm{mL}$ vs. $4.6 \pm 1.1 \mathrm{ng} / \mathrm{mL}, \mathrm{p}=0.048$ ) were significantly higher in hypertensive patients than the normotensive ones. The frequency of the symptoms and rate of the ICU requirement were found to be similar. However, the hospital stay duration was significantly shorter in normotensive subjects than the hypertensive subjects $(9.1 \pm 2.2$ days, vs. $11.7 \pm 2.4$ days, $\mathrm{p}=0.001)$.

Table 2. Comparison of outcomes

\begin{tabular}{|c|c|c|c|}
\hline $\begin{array}{l}\text { Biochemistry } \\
\text { Parameters }\end{array}$ & $\begin{array}{l}\text { Hypertensive } \\
(\mathbf{n = 5 0 )}\end{array}$ & $\begin{array}{l}\text { Normotensive } \\
(\mathbf{n}=50)\end{array}$ & $\mathbf{p}$ \\
\hline $\begin{array}{l}\text { Leukocyte count, } \\
103 / \mathrm{mm} 3\end{array}$ & $8.1 \pm 2.7$ & $6.9 \pm 1.9$ & 0.012 \\
\hline $\begin{array}{l}\text { Hemoglobin } \\
(\mathrm{mg} / \mathrm{dl})\end{array}$ & $13.5 \pm 1.8$ & $13.2 \pm 1.8$ & 0.398 \\
\hline Hematocrit, \% & $40.4 \pm 4.7$ & $38.8 \pm 5.5$ & 0.140 \\
\hline $\begin{array}{l}\text { Peak C-reactive } \\
\text { protein, } \mathrm{mg} / \mathrm{L}\end{array}$ & $52.7 \pm 9.7$ & $18.9 \pm 3.7$ & 0.024 \\
\hline $\mathrm{ESR}, \mathrm{mm} / \mathrm{h}$ & $55.5 \pm 5.7$ & $33.4 \pm 5.1$ & $<0.001$ \\
\hline $\begin{array}{l}\text { Fasting glucose, } \\
\mathrm{mg} / \mathrm{dL}\end{array}$ & $90.8 \pm 9.6$ & $88.9 \pm 8.8$ & 0.634 \\
\hline Creatinine, $\mathrm{mg} / \mathrm{dL}$ & $0.95 \pm 0.6$ & $0.76 \pm 0.18$ & 0.036 \\
\hline AST, U/L & $24.6 \pm 10.8$ & $26 \pm 9.4$ & 0.515 \\
\hline ALT, U/L & $36.1 \pm 2$ & $31.9 \pm 14.2$ & 0.230 \\
\hline D-dimer, ng/mL & $1490 \pm 260$ & $610 \pm 61$ & 0.025 \\
\hline $\begin{array}{l}\text { Peak Creatine } \\
\text { kinase (CK), U/L }\end{array}$ & $117 \pm 50$ & $96 \pm 37$ & 0.017 \\
\hline $\begin{array}{l}\text { Peak Troponin I, } \\
\mathrm{ng} / \mathrm{mL}\end{array}$ & $18.6 \pm 49.6$ & $4.6 \pm 3.1$ & 0.048 \\
\hline Peak Pro-BNP & $62.3 \pm 30.1$ & $63.5 \pm 66.6$ & 0.908 \\
\hline ICU requirement, $\mathrm{n}$ & $2(4 \%)$ & $1(2 \%)$ & 0.558 \\
\hline Death, $\mathrm{n}$ & $0(0 \%)$ & $0(0 \%)$ & 0.999 \\
\hline LOS, days & $11.7 \pm 2.4$ & $9.1 \pm 2.2$ & 0.001 \\
\hline
\end{tabular}

AST: Aspartate aminotransferase ALT: Alanine transaminase BNP: Brain natriuretic peptide, ESR: Erythrocyte sedimentation rate LOS: Length of stay ICU: Intensive care unit

\section{DISCUSSION}

This retrospective study shows that patients with COVID-19 and hypertension have higher blood levels of inflammatory markers, higher troponin I concentrations, higher D-dimer and longer hospital stay compared to those without hypertension despite similar symptomatology. However, the ICU requirement rate, indicating disease severity, is similar in hypertensive and normotensive COVID-19 patients. 
Many studies have shown that there is a close relationship between the elevation of the above-mentioned acute phase reactants and the severity and prognosis of COVID-19. For example, Xiaomi et al. in their study with 298 COVID-19 patients (84 died, 214 recovered) in Wuhan / China reported that CRP is an independent marker showing the severity of the disease and poor prognosis. With a cut-off value of 41.4, CRP exhibited sensitivity of $90.5 \%$, specificity of $77.6 \%$, positive predictive value of $61.3 \%$, and negative predictive value of $95.4 \%$. Subgroup analysis revealed that CRP remained robust in accuracy in adverse outcome prediction in patients with different disease severity. In a study of Ying $\mathrm{Xu}$ et al. conducted with 72 COVID-19 patients, D-dimer levels were examined. The D-dimer levels of COVID-19 patients gradually increased with the aggravation of the disease, and the levels of ordinary type $(n=14)$, severe type $(\mathrm{n}=49)$, and critical type $(\mathrm{n}=9)$ were $0.43(0.22,0.89), 0.66$ $(0.26,1.36)$, and $2.65(0.68,15.45) \mathrm{mg} / \mathrm{L}$, respectively, with statistically significant difference $(\mathrm{P}<0.05)$. Compared with the normal D-dimer group, of the patients in the D-dimer elevated group, the levels of WBC, hs-CRP at admission were significantly higher [WBC $(\times 109 / \mathrm{L}): 7.16(5.55,9.75)$ vs. 5.25 (4.59, 6.98), hs-CRP (mg/L): 27.9 (3.4, 58.8) vs. 1.3 $(0.8,6.6)$, with significant differences $(\mathrm{P}<0.05)$. In our study, we observed that the acute phase reactants excessively increased in the hypertensive group. Therefore, COVID-19 is more severe in this group, and thus, the length of hospital stay is prolonged.

Several reports have revealed that patients with preexisting cardiovascular diseases are at high risk for complications of COVID-19. ${ }^{13-15}$ Although the cause of the increased complication rates from COVID-19 in this population is not clear, the clustering impact of hypertension, diabetes, smoking, male gender, and obesity are considered to have roles in poor results in patients with simultaneous COVID19 and cardiovascular diseases. ${ }^{16,17}$ One of the initial studies conducted by Huang et al. showed that the most common comorbidities accompanying COVID-19 were hypertension (30\%), diabetes (19\%), and coronary heart disease (8\%). ${ }^{18}$ Diabetes, hypertension and cardiovascular disease were found to be related to ARDS in COVID-19 patients. ${ }^{19}$ About $75 \%$ of patients who have died because of COVID-19 in
Italy had hypertension. ${ }^{20}$ However, it is controversial whether a causal relationship can be established between severe COVID-19 and hypertension because hypertension is more common in older people, and they are at risk of developing severe COVID-19. Therefore, it is not yet clear whether high blood pressure alone is a risk factor for the development of severe COVID-19. To diminish any confounders that might have an impact in developing severe COVID-19 such as older age, cardiovascular diseases, immunosuppression, and chronic inflammatory diseases, subjects younger than 45 years old and those without any chronic medical disorders except for the hypertension were included in this retrospective study.

According to our findings, in COVID-19 patients with preexisting hypertension, with high inflammatory indicators compared to normotensive COVID 19 patients, the parameters such as C-reactive protein, erythrocyte sedimentation rate and leukocyte count were higher. Moreover, hospital stay, which may somewhat reflect the severity of the disease, is longer in these subjects compared to their normotensive counterparts. However, the rates of ICU requirement, another surrogate of severe COVID-19, were statistically indifferent between the two groups, although the numbers of patients admitted to ICU was higher in hypertensive group. There is no difference between the groups in terms of ICU requirement rate. The reason for this can be explained by the relatively small sample size. With this in mind, we speculate that preexisting hypertension, alone, might be a factor for developing/having severe COVID-19.

Accumulating data support our findings concerning the role of preexisting hypertension in development of severe COVID-19. A pooled analysis of COVID-19 patients with hypertension has shown that hypertension was linked to a roughly 2.5 fold increase in mortality from COVID-19. ${ }^{21}$ The COVID-19 severity was found to be related to hypertension, diabetes and high cholesterol levels according to a recent meta-analysis of 54 articles. ${ }^{22}$ Although a clear association between COVID-19 and hypertension cannot be established, the changes of pathophysiology including cardiac (especially in left) hypertrophy and fibrosis may 
precipitate cardiac damage during COVID-19, and make the subject more susceptible to SARS-CoV-2.12 The higher troponin I levels observed in hypertensive COVID-19 subjects in our study support this consideration. However, there is still a need for more extensive prospective studies to address the role of hypertension in severity of the COVID19.

Some limitations should be mentioned for our study. First of all, the number of cases is not high, so there may not have been a significant difference between the study groups in terms of mortality and ICU requirement rates.

Second, it is a retrospective study that cannot exclude potential biases. Finally, patients were not followed up after hospital discharge to see any potential impact of hypertension on the long-term follow-up of COVID-19 cases.

In conclusion, findings of this study provide important evidence regarding the effect of preexisting hypertension on the severity of the COVID-19. Our findings show that patients with COVID-19 and hypertension have higher inflammatory markers such as troponin, and longer hospital stay duration compared to COVID-19 patients without hypertension. It appears that hypertensive COVID-19 patients suffer from more severe COVID-19 than normotensive ones. However, further research is needed to indicate whether there is a causal relationship between hypertension and severe COVID-19.

\section{Conflict of Interest}

The authors declare that there is not any conflict of interest regarding the publication of this manuscript.

\section{Authors' Contributions}

Concept/Design: MK. Data Collection and/or Processing: MK. Data analysis and interpretation: MK. Literature Search: MK. Drafting manuscript: MK. Critical revision of manuscript: MK. Supervision: MK.

\section{REFERENCES}

1. Joshi S, Parkar J, Ansari A, et al. Role of favipiravir in the treatment of COVID-19. Int $J$ Infect Dis. 2021;102:501-508.

2. Harapan H, Itoh N, Yufika A et al. Coronavirus disease 2019 (COVID-19): A literature review. J Infect Public Health. 2020;13(5):667-673

3. $\mathrm{Li} \mathrm{X}, \mathrm{Xu} \mathrm{S}, \mathrm{Yu} \mathrm{M}$ et al. Risk factors for severity and mortality in adult COVID-19 inpatients in Wuhan. J Allergy Clin Immunol. 2020;146 (1):110-118.

4. Zhou F, Yu T, Du R et al. Clinical course and risk factors for mortality of adult inpatients with COVID-19 in Wuhan, China: a retrospective cohort study. Lancet. 2020;395(10229):1054-1062.

5. Kumar A, Arora A, Sharma P et al. Is diabetes mellitus associated with mortality and severity of COVID-19? A meta-analysis. Diabetes Metab Syndr. 2020;14(4):535545.

6. Weston S, Frieman MB. COVID-19: Knowns, Unknowns, and Questions. mSphere. 2020;5(2):e020320.

7. Shahid Z, Kalayanamitra R, Mcclafferty B et al. COVID-19 and Older Adults: What We Know. J Am Geriatr Soc. 2020;68(5):926-929.

8. Weiss P, Murdoch DR. Clinical course and mortality risk of severe COVID-19. Lancet. 2020;395(10229):10141015 .

9. Zhang L, Yan X, Fan Q et al. D-dimer levels on admission to predict in-hospital mortality in patients with Covid-19. J Thromb Haemost. 2020;18(6):1324-1329.

10. Apicella M, Campopiano MC, Mantuano $\mathrm{M}$ et al. COVID-19 in people with diabetes: understanding the reasons for worse outcomes. Lancet Diabetes Endo. 2020;8(9):782-792.

11. Gao C, Cai Y, Zhang $\mathrm{K}$ et al. Association of hypertension and antihypertensive treatment with COVID-19 mortality: a retrospective observational study. Eur Heart J. 2020;41(22):2058-2066.

12. Kulkarni S, Jenner BL, Wilkinson I. COVID-19 and hypertension. J Renin Angiotensin Aldosterone Syst. 2020;21(2):1-5.

13. Yahia F, Zakhama L, Ben Abdelaziz A. COVID-19 and Cardiovascular diseases. Scoping review study. Tunis Med. 2020;98(4):283-294.

14. Hulot JS. COVID-19 in patients with cardiovascular diseases. Arch Cardiovasc Dis. 2020;113(4):225-226.

15. Kang Y, Chen $T$, Mui D et al. Cardiovascular manifestations and treatment considerations in covid-19. Heart. 2020;106(15):1132-1141.

16. Akhmerov A, Marbán E. COVID-19 and the Heart. Circ Res. 2020;126(10):1443-1455.

17. Guo J, Huang Z, Lin L, Lv J. Coronavirus Disease 2019 (COVID-19) and Cardiovascular Disease: A Viewpoint on the Potential Influence of Angiotensin-Converting Enzyme Inhibitors/Angiotensin Receptor Blockers on Onset and Severity of Severe Acute Respiratory Syndrome Coronavirus 2 Infection. J Am Heart Assoc. 2020;9(7):e016219.

18. Huang C, Wang Y, Li X et al. Clinical features of patients infected with 2019 novel coronavirus in Wuhan, China. Lancet. 2020;395(10223):497-506.

19. Wu C, Chen X, Cai Y et al. Risk Factors Associated With Acute Respiratory Distress Syndrome and Death in Patients With Coronavirus Disease 2019 Pneumonia in Wuhan, China. JAMA Intern Med. 2020;180(7):934943.

20. Kreutz R, Algharably EaE, Azizi M et al. Hypertension, the renin-angiotensin system, and the risk of lower respiratory tract infections and lung injury: implications 
for COVID-19. Cardiovasc Res. 2020;116(10):16881699.

21. Lippi G, Wong J, Henry BM. Hypertension in patients with coronavirus disease 2019 (COVID-19): a pooled analysis. Pol Arch Intern Med. 2020;130(4):304-309.
22. Zaki N, Alashwal H, Ibrahim S. Association of hypertension, diabetes, stroke, cancer, kidney disease, and high-cholesterol with COVID-19 disease severity and fatality: A systematic review. Diabetes Metab Syndr. 2020;14(5):1133-1142. 